\title{
Overview and Breeding Strategies of Table Potato Production in Sweden and the Fennoscandian Region
}

\author{
Dennis Eriksson $^{1}$ • Ulrika Carlson-Nilsson ${ }^{2}$. \\ Rodomiro Ortíz ${ }^{2} \cdot$ Erik Andreasson ${ }^{1}$
}

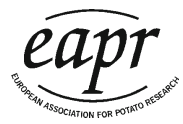

Received: 31 July 2015 / Accepted: 14 September 2016 /

Published online: 28 October 2016

(C) The Author(s) 2016. This article is published with open access at Springerlink.com

\begin{abstract}
Recent reductions in the public commitment to potato breeding in Sweden, Norway and Finland call for an evaluation of the current situation regarding the commercial basis for, and structure of, potato breeding in these countries. We here review the extent of cultivation, processing and consumption of table potato in Sweden, as well as provide an overview of the potato breeding tools and programmes in the three countries. We then discuss various strategies to provide long-term stability and increase the impact of public potato breeding, based on the similar overall conditions for potato cultivation across the Fennoscandian region. The conclusions are twofold; first, an increased long-term funding of the public potato breeding programmes is necessary to maintain a minimum level of material, and second, a coordination of the breeding activities in the Fennoscandian region would be of great benefit to all involved stakeholders and allow an enhancement of the current national breeding programmes. In addition, we propose a minimum first field year population size for potato breeding.
\end{abstract}

Keywords Breeding $\cdot$ Breeding strategy $\cdot$ Breeding target $\cdot$ Fennoscandia $\cdot$ Potato

Electronic supplementary material The online version of this article (doi:10.1007/s11540-016-9328-6) contains supplementary material, which is available to authorized users.

Dennis Eriksson

dennis.eriksson@slu.se

1 Department of Plant Protection Biology, Swedish University of Agricultural Sciences, Box 102, SE-230 53 Alnarp, Sweden

2 Department of Plant Breeding, Swedish University of Agricultural Sciences, Box 101, SE-230 53 Alnarp, Sweden 


\section{Introduction}

Potato is the world's third most important staple crop and an irreplaceable part of the diet in Sweden, Norway and Finland. Unlike cereals, potato is not a commodity that is being largely traded on the world market and the consumption tends to be based on regional production. Hence, the long-term supply of potato depends on cultivars that are adapted to the particular conditions and demands of the region. In the case of the Fennoscandian countries (Sweden, Norway and Finland), this includes relatively short and intense seasons with long day length, specific pathogen pressure, and specific consumer preferences. At the same time, potato has the highest yield potential of all crops in the Nordic region. Despite this, the governments of these countries have reduced the commitment to public breeding, and the current public potato breeding programmes are relatively small, or even closed as in the case of Finland. We therefore see the need for a review of the present situation regarding the structure of, as well as potential, necessity and commercial basis for, potato breeding in the Fennoscandian region. The analysis of potato production, processing and consumption in this study will focus mainly on Sweden. The overview of breeding targets and available breeding tools is generally applicable to the entire Fennoscandian region, given the similar overall geographic and climate conditions and technology infrastructure. We also suggest and discuss various strategies to strengthening potato breeding in Sweden in relation to the current strategies in the neighbouring Norway and Finland.

\section{Brief Historical Overview of Potato Breeding in Sweden, Norway and Finland}

Potato (Solanum tuberosum) was introduced to Sweden by Olof Rudbeck, who grew potato plants in the botanical garden in Uppsala in 1658, and Jonas Alströmer facilitated the spreading of potato cultivation in Sweden from 1720s onwards. This nutritious tuber contributed to the rapid population growth in Sweden in the early 19th century (Svensson 1996). Potato has ever since been a major and irreplaceable part of the Swedish diet. In 2012, the area of potato cultivation was 23,900 ha in Sweden, 21,000 ha in Norway and 13,000 ha in Finland. Potato breeding also has a century-long history in Sweden. The first systematic and scientific breeding activities started at the Swedish Seed Association (Svalöf), a semipublic breeding institute, in Svalöv in 1903. The early breeding targets were high tuber yield, early maturity and tuber bulking, consumption quality and host plant resistance to pathogens. Late blight, caused by the oomycete Phytophthora infestans, was already then a serious constraint in potato cultivation. In 1911, the private company W. Weibulls also initiated a potato breeding programme, utilizing old Swedish farmers' cultivars as well as British, German and Polish cultivars, but this programme was terminated in the 1940s. Around 1950, there were 118 distinct potato cultivars grown by farmers in Sweden, including 12 cultivars from Svalöf and Weibulls (Online Resource 1).

A significant widening of the breeding material at Svalöf was accomplished in 1957 through collaboration with the breeding institute Kartoffelfondens Foraedlingsstation in Denmark. The entire potato breeding programme was further expanded in 1963 with major public as well as private investments, enabling an annual screening of about 100,000 firstyear clones. In the 1970s, the breeding programme was further expanded by inclusion of material from the Rockefeller Foundation in Mexico and the International Potato Center 
(CIP) in Peru. The need of a larger market to motivate investments in breeding led to establishments of new international contacts and partnerships after the formation of the joint public-private company Svalöf AB in 1980. Svalöf AB and W. Weibull AB joined forces in 1993 to form Svalöf Weibull AB (SW), including the potato breeding activities of W. Weibull AB in Emmeloord, the Netherlands (Nordic Genetic Resource Centre 2001). This potato breeding programme was based on a long-term collaboration with Agrico. As a result, agreements were signed with Agrico on the international marketing of potato cultivars resulting from the Swedish programme (Anders Nilsson, the Swedish University of Agricultural Sciences (SLU), personal communication 2015). Until the mid-1990s, there were 28 registered potato cultivars from breeding programmes in Sweden (Online Resource 1). Throughout this time, the company continued to receive public support for its Swedish potato breeding programme. In 2006 though, SW decided to terminate potato breeding for the Swedish market, and the publicly supported breeding programme for Sweden was transferred to SLU and based in its campus at Alnarp, Skåne.

Norway also has a long history of potato breeding. Field trials at Landbrukshøgskolen (NLH) led to the marketing of two cultivars in 1908 and 1910, and systematic potato breeding started in 1920. As in Sweden, potato was extremely important for the national food supply in the 1920s, 1930s and during the World War II, and in 1939, all potato breeding activities were assembled into NLH. In 2002, Graminor Ltd. was established by merging Norwegian plant research and development into one company and the potato breeding programme at NLH was transferred there. The owners of Graminor are the farmers' cooperative Felleskjøpet Agri (37\%), the Ministry of Agriculture and Food (34\%), Lantmännen AB (15\%), Strand Unikorn (9\%) and Gartnerhallen (5\%), which operates from Bjørke Research Station, near the city of Hamar in southeastern Norway (Graminor 2015). Their general breeding goals are to develop cultivars that provide high and stable production of good quality, high host plant resistance to pathogens, and adaptation to anticipated climate change as well as consumer preferences and environmental requirements. They have a long-term agreement since 2006 with Agrico for testing of elite material and marketing of new cultivars (Muath Alsheik, Graminor AS, Norway, personal communication 2015). Graminor has a national market share of approximately $30 \%$ for potato bredcultivars, and its latest cultivars 'Berle' and 'Odinia' were released in 2008 and 2011, respectively (Graminor 2015).

In Finland, Boreal Plant Breeding Ltd. ensued from the merging of materials, know-how and traditions from Finnish plant breeding in 1994, and the Finnish government today owns 60\%. The partnership since 2011 with Limagrain, an international agricultural cooperative specialized in field seeds, vegetable seeds and cereal products, has furthered Boreal's internationalization. However, the breeding programme for table potato was terminated in the end of the 1990s, and the starch potato breeding was terminated in 2014 (Markku Äijälä, Boreal Plant Breeding Ltd., Finland, personal communication 2015).

\section{Potato Consumption in Sweden, Norway and Finland}

Starting already in the early post-war period, there has been a declining trend in fresh potato consumption in Sweden (Fig. 1), paralleled since the 1960s with an increase in the consumption of processed potato, pasta and rice. This trend is similar in Norway. In Finland though, the consumption has been relatively stable since the mid-1980s, and in Sweden, 


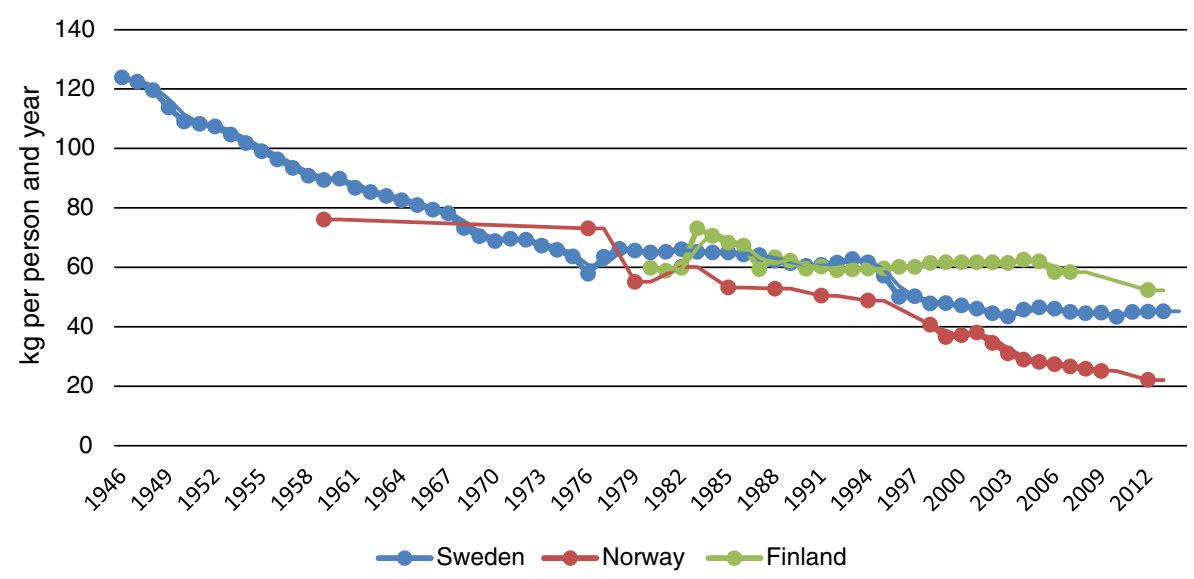

Fig. 1 Consumption of table potato in Sweden, Norway and Finland 1946-2013 (kg person ${ }^{-1}$ year $^{-1}$ ) (ref: Swedish Board of Agriculture 2016; Statbank, Statistics Norway 2016; Statistics Finland 2016)

there is the tendency to stabilization in the last two decades (Swedish Board of Agriculture 2016; Statbank, Statistics Norway 2016; Statistics Finland 2016). A recent study on consumers' attitudes to potato consumption indicated that different aspects of comfort in relation to the shopping and preparation of potato, rather than health aspects, has had an influence on the declining trend of potato consumption in Sweden (Fernqvist et al. 2015), explaining the decrease in consumption of fresh potato in favour of consumption of processed potato, pasta and rice. Nevertheless, potato is still the only major source of carbohydrates for direct human consumption cultivated in the region, as well as an important source of vitamin $\mathrm{C}$ and antioxidants, and continues to be a large and important part of peoples' daily diet. Likewise, the value chain for potato has increased considerably in the last two decades because much more processed potato products are consumed (Fig. 2) (Yearbook of Agricultural Statistics 2014). The first Swedish outdoor restaurant only serving potato products started in 2015, indicating a trend towards a renewed interest in potato.

\section{Production of Potato in Sweden}

\section{Area and Harvest}

In Sweden, cultivation of table potato is mainly in the counties of Skåne, Halland, Västra Götaland and Östergötland (approximately $55^{\circ} \mathrm{N}-59^{\circ} \mathrm{N}$ ). The total area of potato cultivation in Sweden was 23779 hectares (ha) in 2014, with 17638 ha (74\% of the total area) dedicated to table potato. Production of early potato cultivars made up about $19 \%$ of the area of table potato cultivation. For table potato, the average yield was $31.3 \mathrm{t} \mathrm{ha}^{-1}$ in 2014 , a relatively low tuber yield when compared with the major potato producing European countries such as Germany and The Netherlands (Table 1). The total harvest of non-starch potato that year was 551,600 t. Apart from potato for fresh consumption, this includes potato for production of crisps, French fries, mash, cattle feed and seed potato. In 2014, there were 2929 registered farms in Sweden with commercial table potato production. There is a clear, long-term trend towards fewer and larger farms in the whole Fennoscandian region. 


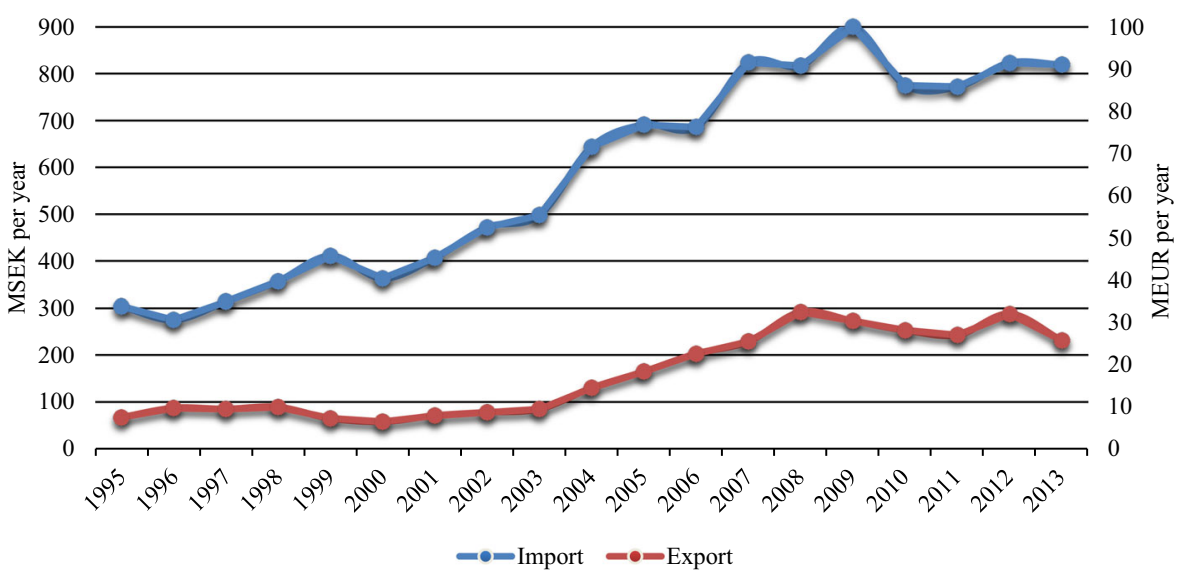

Fig. 2 Swedish import and export of processed potato products 1995-2013 (million SEK year ${ }^{-1}$ ) (ref: Yearbook of Agricultural Statistics 2014)

Cultivation of potato by home gardeners represents a significant amount of the production in Sweden. The total amount of potato produced in 2002 this way was estimated to about $58,000 \mathrm{t}$, with an average yield of about $8.1 \mathrm{t} \mathrm{ha}^{-1}$. That year, the harvest from garden cultivation of potato grown on more than 7,000 ha corresponded to about $9 \%$ of the total commercial harvest of food potato in Sweden (Mortensson and Wahlstedt 2002). Another study, conducted on behalf of Fritidsodlingens riksorganisation (FOR, a national organization for home gardeners), estimated that the amount of home-grown potato produced in Sweden had increased to about $92,000 \mathrm{t}$ in 2011 or $17 \%$ of the total commercial agricultural food potato production.

\section{Cultivars}

In the 2014 season, there were at least 15 major commercial seed potato suppliers providing Swedish farmers with 181 food potato cultivars (Online Resource 2). By far, the most

Table 1 Table potato yields of selected European countries and the world (Source: FAOSTAT 2014)

\begin{tabular}{ll}
\hline Country & Yield $\left(\mathrm{t} \mathrm{ha}^{-1}\right)$ \\
\hline Sweden & 31.3 \\
Norway & 28.9 \\
Finland & 27.3 \\
Belgium & 54.0 \\
Denmark & 43.1 \\
France & 47.9 \\
Germany & 47.4 \\
Netherlands & 45.7 \\
Poland & 27.8 \\
UK & 30.1 \\
World & 20.1 \\
\hline
\end{tabular}


common cultivar is still 'King Edward VII'. This cultivar originated in England more than a hundred years ago and has a very floury texture, which is highly appreciated in many parts of Sweden; however, it is highly sensitive to P. infestans infection. Cultivation has lately been shifted somewhat to the north, particularly to the counties of Värmland and Dalarna, because of the relatively lower pathogen pressure (L. Elofsson, Svensk Potatis AB, Sweden, personal communication 2015). Table 2 lists the area dedicated to certified seed potato production of early and late table potato in Sweden in 2014, with 489 ha dedicated to late potato cultivars and 147 ha to early potato cultivars (Swedish Board of Agriculture 2014). Non-certified seed potato, such as farm-saved seed potato, is, however, being used in Sweden and therefore the actual extent of cultivation of each of the above-mentioned cultivars may be different. The amount of certified seed potato has been estimated at approximately one third of the total volume used (Swedish Board of Agriculture 2006). Lately, a novel category of potato has appeared on the market shelves, the so-called delicacy potatoes with soft and buttery flavour. Among these, 'Amandine' is the most prominent cultivar (L. Elofsson, Svensk Potatis AB, Sweden, personal communication 2015).

\section{Economy}

The primary production value of the Swedish food potato production, including seed potato, was 1822 million SEK (approx. $€ 200$ million) in 2012, which corresponded to $6.9 \%$ of the total primary production value of agricultural crops that year (Yearbook of Agricultural Statistics 2014). The wholesale value of this production was 3,500 to 4,000 million SEK ( $€$ 390-440 million), whereas the market value of table and processed potato from Swedish farms was approximately 5,000 to 6,000 million SEK (approx. $€ 600$ million) (Lisa Germundsson, SLU, personal communication 2014). The same year, processed potato food products at a value of 288 million SEK ( $€ 32$ million) were exported from Sweden and the import of processed potato food products amounted to 823 million SEK ( $€ 91$ million) (Fig. 2). During the last 20 years, the import and export of processed food potato has tripled (Yearbook of Agricultural

Table 2 Area of certified seed potato production in Sweden in 2014. The full list is available as Online Resource 3 (Source: Swedish Board of Agriculture 2014)

\begin{tabular}{lrrlrr}
\hline Mid late and late potato cultivars & \multicolumn{1}{c}{ ha } & \multicolumn{1}{c}{ Early potato cultivars } & ha & \multicolumn{2}{c}{$\%$} \\
\hline King Edward & 216.4 & 44.3 & Solist & 21.2 & 14.4 \\
Mandel & 40.5 & 8.3 & Michelle & 19.7 & 13.4 \\
Bintje & 34.7 & 7.1 & Alexia & 16.5 & 11.2 \\
Fontane & 29.0 & 5.9 & Rocket & 13.9 & 9.5 \\
Fakse & 27.1 & 5.5 & Princess & 11.3 & 7.7 \\
Excellency & 17.8 & 3.6 & Others & 64.2 & 43.7 \\
Perlo & 14.4 & 2.9 & Total & $\mathbf{1 4 6 . 8}$ & $\mathbf{1 0 0}$ \\
Gala & 13.4 & 2.7 & & & \\
Others & 95.6 & 19.5 & & & \\
Total & $\mathbf{4 8 8 . 9}$ & $\mathbf{1 0 0}$ & & & \\
\hline
\end{tabular}

The bold entries in the table denote the sum of all values in ha (columns "ha") or percent (columns "\%") 
Statistics, 2014). Despite occupying only $0.9 \%$ of the area under cultivation in Sweden, potato production still consumed $21 \%$ of all fungicides in Swedish agriculture in 2013. The same year, the average number of applications of fungicides to control P. infestans in Swedish potato production was 8.4 per ha and season (Yearbook of Agricultural Statistics 2014) and can be estimated to be around 10 times if only table potato is considered because starch potato cultivars are generally more late blight resistant. This frequent use of pesticides is a potential market problem that also could be expected to increase. Climate change will also likely increase late blight severity in the northern parts of Fennoscandia. An ex ante analysis related to genetically modified (GM) crops indicated that a late blight resistant potato would enable annual savings of approximately 4,000 SEK ( $€$ 444) per ha (Fagerström and Wibe 2011) or in total 95 million SEK ( $€ 10.5$ million) per year. This is in line with an estimation from the Swedish starch potato growers that one spray cost $425 \mathrm{SEK} \mathrm{ha}^{-1}$ in 2014. With an average of 8.4 sprayings per year in relative resistant starch potato, this would then equal an annual cost of 3570 SEK ( $€ 397) \mathrm{ha}^{-1}$ and approximately a total cost of 85 million SEK ( $€ 9.4$ million), given a potato area of 23,779 ha in 2014 in Sweden.

\section{Current Potato Breeding in Sweden}

\section{Potato Genetic Resources}

The Nordic Genetic Resource Centre (NordGen) is a centre for the conservation of genetic resources for agriculture in the Nordic countries. The potato collection held by NordGen consists of 64 local, old potato cultivars (Online Resource 4), which are stored in vitro as small plantlets (Nordic Genetic Resource Centre 2001). Nonetheless, the conservation carried out by hobby growers and small-scale commercial farmers is also important. Two examples are Orupsgården (www.orupsgardenspotatis.se) and Larsviken (www.larsviken.se), which currently maintain more than 500 and 550, respectively, potato cultivars. The old potato landraces have considerable cultural and historical value in the region. However, as breeding material, they currently can be difficult to use as they tend to perform poorly and also do not have clear traits that would be valuable for introgression into today's common commercial cultivars. The use of wild Solanum species is often more interesting for potato breeding for pathogen resistance breeding (Ortiz 1998).

\section{Current Investments in Potato Breeding}

After the transfer of the Swedish potato breeding programme to SLU, the Government of Sweden announced its intention to invest in public plant breeding (Government Proposition 2008). A directive was given to SLU in 2009 to carry out plant breeding specific for the conditions in northern regions (Government Directive 2009). In 2009$2015,1.0$ to 2.1 million SEK ( $€ 0.11-0.23$ million) annually has been allocated to potato breeding in Sweden from various governmental sources as well as co-funding from SLU. The potato breeding activities at SLU in Alnarp are largely focused on developing table potato cultivars with late blight resistance and high yield for the Swedish market. Two more breeding targets are also of high priority: high cooking 
quality and skin finish, as well as cultivars that are suitable for cultivation at different latitudes in Sweden. Field trials are carried out in Kristianstad (56 $6^{\circ} 1^{\prime} 54^{\prime \prime} \mathrm{N} 14^{\circ} 9^{\prime} 17^{\prime \prime}$ E) and Borgeby $\left(55^{\circ} 44^{\prime} 0^{\prime \prime} \mathrm{N} 13^{\circ} 1^{\prime} 55^{\prime \prime} \mathrm{E}\right)$ as well as in Umeå $\left(63^{\circ} 49^{\prime} 32^{\prime \prime} \mathrm{N} 20^{\circ} 15^{\prime}\right.$ $49^{\prime \prime}$ E). Until recently, a GM trait programme to develop a potato with host plant resistance to $P$. infestans, using a stack of two different resistant genes, was carried out at BASF Plant Science (BPS), jointly owned by BASF and Svalöf Weibull. The first field trials were carried out in 2006 in Sweden, and a transformation event in the cv. 'Fontane' background was dedicated to become the first GM-based potato with resistance to $P$. infestans. However, the project was discontinued in 2012 due to uncertainties to get market approval for GM cultivars in the EU.

\section{Breeding Targets}

It is crucial that potato cultivars bred for northern Europe are able to show high and marketable yield under the particular geographic and climatic conditions of this region in combination with quality characteristics appreciated by the consumers. Potato cultivated in Sweden needs early tuber maturity due to the short season, as well as insensitivity to the long day length of the summer. The optimal potato for this region is one that can utilize the many hours of light. The phytopathogenic profile is also specific, with relatively suitable climatic conditions for late blight infection. In Sweden, both of the known mating types (A1 and A2) of P. infestans are present, enabling the pathogen to multiply both vegetatively and sexually, and a unusual high local diversity of populations even within fields has been documented (Sjöholm et al. 2013). Sexual reproduction leads to accelerating genetic change and diversification, and the overwintering oospores serve as inoculum in the spring (Andersson 2007). Development and implementation of new resistant cultivars is the most economical and ecological way to fight $P$. infestans. Therefore, high yield at Nordic conditions together with late blight resistance may be considered the primary breeding targets for a Swedish potato breeding programme. A combination of late blight resistance and high and stable marketable yield in this part of the world would certainly be enough for success. Stable late blight resistance is also generally not a primary breeding target in commercial breeding programmes.

Other important breeding targets include further disease resistance and quality traits to meet consumer preferences. Early blight (Alternaria solani) and bacterial soft rot (Dickeya, Erwinia) are diseases that are increasing in importance (Blixt and Andersson 2010; Toth et al. 2011; Potrykus et al. 2014). Also, inner discolouration as a result of reactions on infection of tobacco rattle or mop top virus is more frequent in northwest Europe than in other parts of Europe and can make the crop unsuited for marketing (Anders Nilsson, SLU, personal communication 2015). The on-going climate change may alter the phytopathogenic profile and also stresses the importance of specific potato breeding for this region. A particular preference for taste and texture, such as the appreciated floury cultivar 'King Edward VII', is also important to consider as this is generally not a major breeding target.

Breeding targets that are not particularly relevant for environments or markets in Sweden include adaptation to drought because water shortage is rarely an issue in this country. The visual tuber appearance is of increasing importance as consumers ask for potatoes with a pleasant shape and skin and homogenous size of tubers. Potato breeding 
towards more and more specific cultivars for particular end uses, such as delicacy potato, is also a significant development. Important as they may be, these traits would possibly be of lower priority in relation to the traits mentioned above, in a limited breeding programme targeting the Swedish or Fennoscandian market. Organic farming and home gardening may have different priorities for the main traits. The restrictions on pesticides and synthetic fertilizers demand cultivars that have high nutrient use efficiency as well as an excellent resistance to P. infestans tuber and foliage blight. Tuber yield and shape are still important because of large-scale commercial cultivation in organic farming, though not in home gardening. For organic farming, it is also important that the cultivar is robust and stable when it comes to uneven supply to fertilizer, shows vigour at early growth, and matures early with acceptable cooking quality. However, the relative scale of organic potato farming, at about 800 ha, or about $3 \%$ of the total area of potato cultivation, annually (Yearbook of Agricultural Statistics 2014), and home gardening (Mortensson and Wahlstedt 2002; Andersson et al. 2011) does not currently motivate potato breeding for these particular segments. Nevertheless, the organic sector will also likely benefit as the breeding targets overlap to some extent with what has been outlined as our main priorities, particularly early tuber maturity and late blight resistance.

\section{Specific Breeding Tools}

The commonly cultivated potato (Solanum tuberosum) is a self-compatible polysomic tetraploid $(2 n=4 x=48)$, which shows tetrasomic inheritance and inbreeding depression after continuous self-fertilizing. Potato breeding has traditionally involved making crosses between pairs of parents with complementary features based on phenotype (Bradshaw and Bonierbale 2010). Diploid breeding may also lead to developing true $F_{1}$ hybrid potato seed derived from crossing non-related self-compatible homozygous diploids (Lindhout et al. 2011).

Marker-assisted selection (MAS) in potato has been used for selection of host plant resistance genes with major effects, e.g. for cyst nematode and Potato virus $Y$ (Ortega and Lopez-Vizcon 2012; Whitworth et al. 2009). It also looks promising for tuber quality features ( $\mathrm{Li}$ et al., 2013). MAS along with the estimation of breeding values for simple and complex traits may improve the efficiency in future potato breeding since it will likely reduce significantly the time for identifying superior germplasm (Slater et al. 2013; Slater et al. 2014). Dense genetic maps based on single nucleotide polymorphisms (SNPs) give details about location of quantitative trait loci (QTL) and serve to develop genetic models that account for phenotypic variation. The potato genome sequence (Potato Genome Sequencing Consortium, 2011) provides further means for genome-wide assays and tools for gene discovery and enables the development of marker haplotypes spanning QTL regions. They will probably be very useful in introgression breeding and a whole-genome approach such as genomic prediction for selection (Barrell et al. 2013), thus improving the efficiency of selecting elite clones and enhancing genetic gain over time (Abera and Ortiz 2014). Recently, also the first genome of a tuber-producing wild potato species was published (Aversano et al. 2015). We currently use five markers for late blight resistance in the Swedish potato breeding programme, of which one has been generated from the old SW material (Ali et al. 2012; Lenman et al. 2016). This is essential for stacking genes for late blight resistance. 
Another recent method that shows great potential for potato breeding is site-directed mutagenesis (or genome editing), which allows particular sequences in a given gene to be modified. Whether or not plants modified in this way will be classified as GMOs is still unclear in the EU, but as a tool for specific genetic modification, it shows great potential. One of the co-authors participated in the development of a method for sitedirected mutagenesis using transcription activator-like effector nucleases (TALENs) in tetraploid potatoes via protoplasts and without any stable integration of novel DNA (Nicolia et al. 2015), and is now adopting this to clustered regularly interspaced short palindromic repeats (CRISPR)/Cas9 methodology. For example, increased pathogen resistance is now introduced through disruption of susceptibility genes and can be done directly into the most popular cultivars. Also genomic selection as well as RNA, protein and metabolite — omics data are revolutionizing our ways of breeding for example to be able to predict in the first clonal generation many of the phenotypes or finding new susceptibility and resistance genes.

\section{Lower Limit of Breeding Population Size of Tetraploid Potato Breeding}

A relevant issue regarding a potato breeding programme with limited resources is the size of the initial, first clonal generation, as a large population of potato clones requires a lot of resources. Lindhout et al. (2011) mentioned that it typically takes 100,000 seedlings to generate one new cultivar. The potato breeding programme at Sveriges Utsädesförening in Svalöv also estimated in 1963 that a suitable size of a breeding population would be about 100,000 seed plants per year. This would presumably have resulted in one new cultivar yearly after about 14 or 15 years of field trials and seed potato production with the selection techniques of those times (Nordic Genetic Resource Centre 2001). Potato breeding at the Scottish Crop Research Institute, prior to 1982 , arrived at a similar conclusion and started with 100,000 greenhouse-grown seedlings for visual selection, followed by 40,000 spaced plants in the first clonal generation (Gopal 2006). However, such intensive early-generation visual selection of individual clones is generally ineffective. There are reports that repeatability of the performance of clones selected in early generations is low in subsequent generations (Caligari 1992; Bradshaw et al. 1998). This is of course also dependent on the particular trait in question.

In a recent article from The Netherlands, a company is classified as large if it manages more than 50,000 first-year clones, medium with 15,000 to 50,000 clones and small with less than 15,000 clones (Almekinders et al. 2014). In one of these medium size companies, namely Fobek B.V., selection during three consecutive field generations reduced the original population to $1 \%$ of the clones, and after five generations of selection, $0.17 \%$ remained. This result would imply a potato breeding programme resulting in 25 to 85 elite clones after five field generations (Keijzer P, Fobek B.V., The Netherlands, personal communication 2014). Another potato breeding programme at the Walloon Agricultural Research Centre in Belgium has, over the last decade, screened 1750 to 12,000 first-year clones per year, which resulted in 2 to 26 elite clones after 3 to 7 years of selection. Taken together, this means that approximately 0.09 to $0.22 \%$ of the original population remains as elite breeding material after 3 to 7 years of selection. The particular target for the breeding programme at the Walloon Agricultural Research Centre is late blight resistance, and the staff managing the 
programme suggest that the focus on this trait may decrease the number of elite clones since it is hard to combine with other traits, such as tuber yield, other tuber features, and processing or cooking quality (A. Soete, Walloon Agricultural Research Centre, Belgium, personal communication 2015). The present setup at SLU just about manages approximately 10,000 first field year clones and aims at 100 clones in the 3rd field year, five to ten clones in the 5th field year and one or two clones in the 7th field year. This size of the first field year clone population is proposed by us to constitute the lower limit for potato breeding in order to have a reasonable chance of acceptable delivery.

\section{Cost and Benefit of Potato Breeding in Sweden}

As potato is not a commodity that is being traded to any large extent on the global market, table potato consumption depends mainly on regional production. To maintain a reasonable level of agricultural output without major environmental concerns for this crop, it is of outmost importance that a steady supply of regionally suitable cultivars is secured to farmers in Sweden. The relatively small market sizes of Sweden, Norway and Finland is not sufficient motivation for the major potato breeding companies and seed potato suppliers in Europe to specifically invest in potato breeding that matches the specific requirements of this Fennoscandian region. A national strategy for potato breeding coupled with selective public investments is therefore essential to support and maximize this supply in the future.

\section{The Current Situation}

The Swedish seed potato market is currently dominated by two Dutch companies (Agrico and HPZC) and one Danish company (Danespo), which either export seed potatoes to Sweden or, more commonly, have seed production in Sweden of their own cultivars. Independent seed potato producers are mostly restricted to produce older cultivars such as 'King Edward VII'. Swedish potato growers are therefore to a large extent limited to the cultivars developed by these foreign potato breeding companies, who would naturally have a limited focus on Swedish conditions, particularly for the mid- and northern regions of the country. This situation is rather vulnerable and Swedish and Finnish, and to a certain extent also Norwegian, farmers may sooner or later have to face a supply of seed potato material inferior for cultivation in these countries.

\section{Gross Return on Investments in Plant Breeding}

As discussed above, the market value of fresh and processed potato is large in Sweden and there is a large industry of peeling, processing and packing for individual consumers and industrial kitchens, as well as specific and local products that are all dependent on a stable supply of high-quality potato with various properties. Investments in potato breeding therefore have great potential to yield a high gross return. A report from the UK covering the latest 30 years of breeding in wheat, barley and forage maize indicated a gross return on investment of about 40:1. This is a very high number compared to the gross return at 5:1 for investments in fundamental research and 15:1 for investments in applied research in the UK (Webb 2010). We have not found a similar analysis of investments in plant breeding in any Scandinavian country. CIP research shows, however, that an increase of $9 \%$ in tuber yield 
and the reduction of fungicide use as result of growing late blight resistant cultivars translated in a benefit of US\$ 130 per ha for potato farmers in Peru and a 26\% return investment rate (Sevilla and Ortiz 2010). It is therefore reasonable to expect at least a similar outcome in Sweden.

The economic output is also likely to be further exacerbated by recent technical developments. Certain novel techniques, e.g. genomic selection and site directed mutagenesis, hold a great promise to enhance the efficiency of potato breeding (Nicolia et al. 2015) as well as analyses with RNAseq, proteomics, and effector screening (Ali et al. 2014; Chawade et al. 2016; Lenman et al. 2016). Diploid and $F_{1}$ hybrid breeding in potato (for example www.solynta.com) also shows great potential to overcome some of the limitations of traditional crossing with tetraploid material and speed up the development of new hybrid cultivars, thus further increasing the potential economic output. Potato SNP arrays or Illumina sequencing are now used in order to facilitate MAS and in the future genomic selection.

\section{Reasons for Public Investments in Potato Breeding}

There are several reasons for public investments in potato breeding in Sweden and the Fennoscandian regions, some of which are listed here below:

(1) National food self-sufficiency is an issue of high priority. In 2015, the Swedish Government initiated a process to develop a national strategy for food supply, a strategy that will largely emphasize primary production (http://www.regeringen. $\mathrm{se} / \mathrm{sb} / \mathrm{d} / 19810 / \mathrm{a} / 255173)$. A similar vision has also been expressed in Norway (Graminor 2014) and Finland (Palokangas 2010).

(2) The Swedish Parliament has adopted 16 environmental quality objectives (http://www.miljomal.se/sv/Environmental-Objectives-Portal/). At least two of these, A non-toxic environment and A varied agricultural landscape, will greatly benefit from a national potato breeding programme targeting the particular phytopathogenic profile in the region, reducing the need for chemical crop protection by addressing a major fungicide target.

(3) The gross return on investment is generally very high for plant breeding.

(4) The extent as well as growth potential of the national potato industry provides a large amount of employment opportunities in production and processing, here keeping in mind the trend nowadays towards eating more vegetables, and the high non-allergy protein production per ha in potato. Still, the market is too small for any commercial breeder to target this region specifically.

(5) The Fennoscandian region is well suited for potato cultivation with generally enough water supply of good quality and a comparatively moderate pathogen pressure. This is also underlined by the high food value of potato, which has the highest yield per ha of all agricultural crops in Sweden.

(6) Existing cultivars are sensitive to pathogens resulting in frequent fungicide treatments and are not adapted for benefit of the long days in the summer with significantly lower yields.

(7) Potato is an essential component in many of the local dishes that define the Swedish cuisine. As such, it is an integrated part of the Swedish culture and identity. 


\section{Future Scenarios for Fennoscandian Potato Breeding}

Swedish, Norwegian and Finnish potato farmers would be in a vulnerable situation if the three countries should rely exclusively on cultivars bred in other countries and for other breeding targets. No major potato breeding companies from other west or central European countries develop potato cultivars specifically for cultivation at the more northern latitudes of the Fennoscandian countries. With this in mind, we here discuss three different scenarios for the future of potato breeding in Sweden and for the relation to potato breeding programmes in the neighbouring countries Norway and Finland.

\section{Increased Public or Private Funding in Each Country}

The recent increase in first field year clones per year in Sweden to 10,000 just about meets the lower limit for potato breeding as proposed by us. This minimum level of breeding in the Swedish programme is currently sustained with short-term external funding. However, this situation does not correspond to the long-term (8-10 years) process of cultivar development. The Swedish Government has recently initiated a process to develop a long-term strategy for national food supply (http://www.regeringen.se/sb/d/19810 /a/255173). Stable and long-term investments in potato breeding for the Fennoscandian region would be highly relevant and in alignment with this strategy.

\section{Coordinated Breeding and Selection Activities in Sweden, Norway and Finland}

As described in the introduction, there has been a tradition of international collaboration in potato breeding within Sweden, Norway and Finland. Due to the similar geographic and climatic conditions of the three countries, the breeding goals would be similar. The most significant common breeding target is a high and stable yield at northern latitudes, and there are genotypes that do relatively better there. The current focus on pathogen resistance in the potato breeding programmes, in Sweden towards late blight resistance and currently in Norway towards silver scurf (Helmintosporium) resistance, provides a good platform for combining material and gaining mutual benefits. A preference for floury cultivars, such as 'King Edward VII' (Sweden), 'Mandel' (Sweden, Norway) and 'Pito' (Finland), is also common among the three countries. We therefore argue that a coordination of the public breeding and testing efforts would be of great benefit. There is also considerable parliamentary support in Sweden for an increased Nordic collaboration in plant breeding, with several recent parliamentary motions emphasizing the advantages of collaboration within the Nordic region (Parliamentary Motion 2005, 2009, 2010).

In the case of Norway, one impediment to coordinated breeding efforts may be the regulations for import and export of plant material that occur in this country, as it is not a member of the European Union. Any material other than seed and in vitro cultivated tissue is subject to a 2-year quarantine when transferring across the border. Unless an agreement with case-specific exemptions can be reached, any exchange of material within a coordinated breeding would thus be limited to seeds and in vitro plantlets.

One scenario under these conditions could be to reach a common agreement on parent material and crosses, based on common breeding targets, followed by distribution of seeds across the three countries and sharing of results from field testing and evaluation. This approach would make testing more cost efficient for each country while greatly extending 
the data set on which to base elite clone selection. As Sweden is currently managing 10,000 first-year clones and Norway approximately 20,000 (in 2015), coordinated testing and evaluation would imply that the results from the testing of about 30,000 lines are available for analysis. A contribution from Finland would further strengthen the breeding programme, such as for example testing of late selections. Another advantage of this approach is that testing of elite clones in different environments is important to evaluate the full potential of these clones. This kind of coordinated effort would therefore greatly increase the capacity and long-term strategies of potato breeding for the Fennoscandian region.

\section{Outsource Certain Activities to Commercial Counterpart}

Another approach to develop the potato breeding in this region is to establish a mutual agreement for testing and commercialisation of cultivars with an international enterprise. As mentioned in the introduction, Norway already has an agreement with Agrico, a large international potato breeding company from the Netherlands, and Finland has a partnership with Limagrain. A problem with this approach for the Swedish situation is that the outsourcing company will claim their own marketing and sales of cultivars in Sweden, thus becoming a potential competitor. Likewise, it may be politically sensitive to hand over any rights of the breeding material to a foreign seed company. However, a feasible setup for Sweden, similarly to the strategy adopted by Norway, would be to retain exclusive rights to market the cultivars at a national or regional level whereas the private counterpart would gain the right to market the cultivars abroad. The question remains how much efficiency this gains whereas some of the technical parts of the breeding work are already outsourced in Sweden. Given the current situation for potato breeding in Sweden, Norway and Finland, and the potential for establishing a collaboration between the three countries, we would argue that a combination of the scenarios suggested above would be most appropriate to strengthen the potato breeding in this region. An increased and stable funding of the potato breeding programme in Sweden is of outmost importance to maintain at least a minimum level of material. Moreover, coordinated breeding activities in the Fennoscandian region would be of great benefit to all stakeholders and allow an enhancement of the current national breeding programmes.

Acknowledgments We would like to thank the Swedish foundation for strategic environmental research, The Swedish Research Council for Environment, Agricultural Sciences and Spatial Planning as well as Swedish Farmers' Foundation for Agricultural Research for financing this study. Valuable comments to the manuscript from Lotta Rydhmer, Anders Nilsson and Erland Liljeroth have been appreciated. Also communications with Muath Alsheik at Graminor in Norway and Markku Äijälä at Boreal in Finland have provided valuable input to the article.

Open Access This article is distributed under the terms of the Creative Commons Attribution 4.0 International License (http://creativecommons.org/licenses/by/4.0/), which permits unrestricted use, distribution, and reproduction in any medium, provided you give appropriate credit to the original author(s) and the source, provide a link to the Creative Commons license, and indicate if changes were made.

\section{References}

Abera DZ, Ortiz R (2014) Genomic selection: genome-wide breeding value prediction in plant improvement.

Trends Plant Sci 19:592-601 
Ali A, Moushib LI, Lenman M, Levander F, Olsson K, Carlson-Nilson U, Zoteyeva N, Liljeroth E, Andreasson E (2012) Paranoid potato: Phytophthora-resistant genotype shows constitutively activated defense. Plant Signal Behav 7:400-408

Ali A, Alexandersson E, Sandin M, Resjö S, Lenman M, Hedley P, Levander F, Andreasson E (2014) Quantitative proteomics and transcriptomics of potato in response to Phytophthora infestans in compatible and incompatible interactions. BMC Genomics 15(1):497

Almekinders CJM, Mertens L, Loon JP, Lammerts Van Bueren E (2014) Potato breeding in the Netherlands: a successful participatory model with collaboration of farmers and commercial breeders. Food Sec 6:515524

Andersson B (2007) Sexual reproduction in Phytophthora infestans-epidemiological consequences. PhD thesis

Andersson U, Löfstrand A, Persson L, Wangenfors T (2011) Fritidsodlarnas matproduktion i Sverige 2011dess omfattning och ekonomiska betydelse. Fritidsodlingens Riksorganisation

Aversano R et al (2015) The solanum commersonii genome sequence provides insights into adaptation to stress conditions and genome evolution of wild potato relatives. Plant Cell 27:954-968

Barrell PJ, Meiyalaghan S, Jacobs JME, Conner AJ (2013) Applications of biotechnology and genomics in potato improvement. Plant Biotechnol J 11:907-920

Blixt E and Andersson B (2010) Occurrence of Alternaria solani in Sweden and its sensitivity to strobilurins. Twelth EuroBlight workshop, Arras, France, 3-6 May 2010

Bradshaw JE, Bonierbale M (2010) Potatoes. In: Bradshaw JE (ed) Root and tuber crops, Handbook of plant breeding 7. Springer Science + Business Media, New York, pp 1-52

Bradshaw JE, Dale MFB, Swan GEL, Todd D, Wilson RN (1998) Early-generation selection between and within pair crosses in a potato breeding programme. Theor Appl Genet 97:1331-1339

Caligari PDS (1992) Breeding new cultivars. In: Harris P (ed) The potato crop, 2nd edn. Chapman and Hall, London, pp 334-372

Chawade A, Alexandersson E, Bengtsson T, Andreasson E, Levander F (2016) Targeted proteomics approach for precision plant breeding. J Proteome Res 15(2):638-646

Fagerström T and Wibe S (2011) Genvägar eller senvägar? Rapport till Expertgruppen för miljöstudier 2011:3, ISBN 978-91-38-23594-2

Fernqvist F, Spendrup S, Ekelund L (2015) Changing consumer intake of potato - a focus group study. Br Food J 117:210-221

Gopal J (2006) Considerations for successful breeding. In: Gopal J, Khurana SMP (eds) Handbook of potato production, improvement and postharvest management. Food Products Press, New York, pp 77-108

Government Proposition (2008) Sweden, Ett lyft för forskning och innovation

Government Directive, Swedish University of Agricultural Sciences (2009)

Graminor (2014) Annual Report

Graminor (2015) http://graminor.no/no/forsiden, 2015-05-26

Lenman M, Ali A, Muhlenbock P, Carlson-Nilsson U, Liljeroth E, Champouret N, Vleeshouwers VG, Andreasson E (2016) Effector-driven marker development and cloning of resistance genes against Phytophthora infestans in potato breeding clone SW93-1015. Theor Appl Genet 129(1):105-115

Li L, Tacke E, Hofferbert HR, Lubeck J, Strahwald J, Draffehn AM, Walkemeier B, Gebhardt C (2013) Validation of candidate gene markers for marker-assisted selection of potato cultivars with improved tuber quality. Theor Appl Genet 126:1039-1052

Lindhout P, Meijer D, Schotte T, Hutten RCB, Visser RGF, van Eck HJ (2011) Towards $\mathrm{F}_{1}$ hybrid seed potato breeding. Potato Res 54:301-312

Mortensson B, Wahlstedt G (2002) Potatis - konsumtion och fritidsodling. Rapport Statistiska Centralbyrån

Nicolia A, Proux-Wera E, Åhman I, Onkokesung N, Andersson M, Andreasson E, Zhu LH (2015) Targeted gene mutation in tetraploid potato through transient TALEN expression in protoplasts. J Biotechnol 204: $17-24$

Nordic Genetic Resource Centre (2001) Potatis i Norden. Skrifter Nordiska Genbanken 39. Nordiska Genbanken, Alnarp

Ortega F, Lopez-Vizcon C (2012) Application of molecular marker assisted selection (MAS) for disease resistance in a practical potato breeding programme. Potato Res 55:1-13

Ortiz R (1998) Potato breeding via ploidy manipulations. Plant Breed Rev 16:15-86

Palokangas S (2010) Food for tomorrow-proposal for Finland's National Food Strategy. Published by: Steering group for the preparation of the food strategy. Printing house: Vammalan kirjapaino

Parliamentary Motion (2005) MJ493, Sweden, Nordiskt samarbete kring växtförädling

Parliamentary Motion (2009) MJ446, Sweden, Växtförädling för framtidens livsmedelsproduktion

Parliamentary Motion (2010) MJ205, Sweden, Ökad satsning på växtförädling 
Potato Genome Sequencing Consortium (2011) Genome sequence and analysis of the tuber crop potato. Nature 475:189-197

Potrykus M, Sledz W, Golanowska M, Slawiak M, Binek A, Motyka A, Zoledowska S, Czajkowski R, Lojkowska E (2014) Simultaneous detection of major blackleg and soft rot bacterial pathogens in potato by multiplex polymerase chain reaction. Ann Appl Biol 165(3):474 487

Sevilla R, Ortiz R (2010) El impacto económico de la investigación del CGIAR en el Perú. Agrum 33:52-55

Sjöholm L, Andersson B, Högberg N, Widmark AK, Yuen J (2013) Genotypic diversity and migration patterns of Phythophthora infestans in the Nordic countries. Fungal Biol 117:722-730

Slater AT, Cogan NOI, Forster JW (2013) Cost analysis of the application of marker-assisted selection in potato breeding. Mol Breed 32:299-310

Slater AT, Cogan NO, Hayes BJ, Schultz L, Dale MF, Bryan GJ, Forster JW (2014) Improving breeding efficiency in potato using molecular and quantitative genetics. Theor Appl Genet 127:2279-2292

Statbank, Statistics Norway (2016) http://www.ssb.no/en. Accessed 4 January 2016

Statistics Finland (2016) http://www.stat.fi/tup/kirjasto_tieto/tilastolliset_vuosikirjat_en.html. Accessed 4 January 2016

Svensson B (1996) Svensk potatisodling-Utvecklingen under 1900-talet

Swedish Board of Agriculture (2006) Utredning om utsädespotatis, Rapport

Swedish Board of Agriculture (2014) Fältbesiktningsstatistik

Swedish Board of Agriculture, Statistics (2016) https://www.jordbruksverket.se/omjordbruksverket/statistik. Accessed 4 January 2016

Toth IK, van der Wolf JM, Saddler G, Lojkowska E, Helias V, Pirhonen M, Tsror L, Elphinstone JG (2011) Dickeya species: an emerging problem for potato production in Europe. Plant Pathol 60:385-399

Webb D (2010) Economic impact of plant breeding in the UK. Final report, commissioned by the British Society of Plant Breeders. DTZ, Manchester, United Kingdom

Whitworth JL, Novy RG, Hall DG, Crosslin JM, Brown CR (2009) Characterization of broad spectrum potato virus $\mathrm{Y}$ resistance in a Solanum tuberosum ssp. andigena-derived population and select breeding clones using molecular markers, grafting, and field inoculations. Am J Potato Res 86:286-296

Yearbook of Agricultural Statistics (2014) Swedish Board of Agriculture 